\title{
Quantitative translationscapes and chronological constellations: French, Soviet, and American novels in communist Romania
}

\section{ȘTEFAN BAGHIU}

DOI: https://doi.org/10.31577/WLS.2021.13.3.11

In 1842, a rather odd text was published by a French historian, Charles Léopold Louandre, titled "Statistique littéraire: La Poésie depuis 1830", which has remained obscure for literary historians and literary theorists, including distant reading experts. $^{*}$ The text can be seen as peculiar because, although it may seem like a typical statistical account of books put forward during the decade when statistics institutions were emerging in Europe, its metaphors and reflections are not ordinary at all. Louandre writes about a literary necropolis ("nécropole littéraire", 971) as he browses through the legal book depository in Rue de Grenelle and laments the disappearance of specific titles from its bibliography:

I browsed with interest and sadness through so many volumes, which had left behind, as a testimony to their existence but a serial number and a title in the catalog of the library, and I gazed at the poets for a long while, overwhelmed by their number and quite surprised that I only with great difficulty found, among them, a few vaguely familiar names (972, trans. by S.B). ${ }^{1}$

Historians could have easily forgotten Louandre for this text (which, of course, happened), and literary theorists could have fairly neglected him, if it were not for his distinction between the "royalty of poetry, the masters we love to read time and again, who are constantly republished and sold" and the "obscure satellites [...] which form a genuine Milky Way on our firmament" (972, trans. by S.B.). ${ }^{2}$ Louandre theorizes here about "the great unread", a century and a half before the concept gained momentum within world literature studies and long before distant reading and macroanalysis rethought the quantitative analysis of literature (Cohen 1999; Moretti 2000a, 2000b, 2013; Jockers 2013). This great unread is of interest in the present article, mainly through "constellations" of translations within a given space and time, defined by the chronological distance between the original publication of a novel and the release of its first translation in a given target culture. "The great unread" and "the constellation", both useful metaphors in literary studies, primarily convey one central idea: one must understand the workings of the vast literary mass in equal measure to the workings of the canon, and not by extrapolating the canon to the mass, but by deploying various distances (i.e. measures), from which I will

* This work was supported by a grant of the Romanian Ministry of Education and Research, CNCS-UEFISCDI, project number PN-III-P1-1.1-TE-2019-0946, within PNCDI III. 
hereby select and address the chronological ones. The main observation here is that in the exact way distances between stars are calculated through observing them against other stars (against the background of other stars), distance in literature could be seen as reachable through a connection set between the translation and the year of the original publication. This is an example of what Jordan A.Y. Smith convincingly argues to be a useful model in translation studies and world literature, namely translationscapes (2017), or "the sum total of texts of a given literary set visible in another" $(2017,751)$.

Although I have previously discussed the utility of quantitative translationscapes (Baghiu 2019a; 2019b) for the French novel and also for Latin American, Southeast Asian, and African literatures in translation, I have never before conducted a comparative analysis of given translationscapes within a given literary culture. My aim here is to show the utility of such an approach by visualizing translations of novels in Romania between 1944 and 1989, between the conclusion of World War II and the fall of communism. This was a 45 -year period with a state-sponsored literary system, from which I select three translationscapes, each with its specific constellation: the constellations of the French, Russian/Soviet, and American novel.

\section{NATIONAL READINGS OF TRANSLATIONSCAPES FOR WORLD LITERATURE}

The novel had its unique way of becoming a cohesive genre through time thanks to imitations and translations, and it continued its life after becoming cohesive through reprints and retranslations. As Donald Sassoon shows in his The Culture of the Europeans (2012), by the 1830s, the novel entered a new era, in which it would acquire a central position within the evolution of literary genres in Europe. The new age of the novel started when, by the end of the 18th century, "[i]n twenty years, with a striking rapidity, all the forms [of the novel] that will dominate Western narrative for a century [found] their masterpiece" (Moretti 2013, 19). At the same time, as Robert Escarpit showed in The Book Revolution, there are various stages in the large-scale dissemination of literature throughout the continent, and certainly equally as many on a planetary scale: "The Divine Comedy took more than four centuries to make its way throughout Europe; twenty years were enough for Don Quixote, and five for Werther" $(1966,22)$.

Several questions arise: What happened to those masterpieces? Where and when did they travel? What is a masterpiece within a constellation of thousands of translated novels from a specific culture into another? In trying to define the inception of the European novel, Franco Moretti thought, along the lines of Fernand Braudel, that a representation of an "evolutionary bush" could serve as a working instrument for visualizing the genre's development. Braudel described this evolution by formulating a very useful metaphor: "its growth will take the form of slower runners catching up with the leader of the race" (Moretti 2013, 19). The conceptual metaphor I hereby put forward is, alongside Charles Louandre's metaphor of constellations, the chronological translationscape, in which the distances between works can be observed across time for specific contexts. 
The three charts I will present, together with their highlighted versions, show the chronological tendencies of translated novels in a comprehensive account of all the French, Russian (and Soviet), and American novels that were translated in Romania after World War II, using Smith's concept of the translationscape (2017). Smith argues that translations are "ideologically conditioned" (751) and that translated works form scapes within the target culture that become marks for the "visibility of power in world literary production" (755). Of course, translations are not "all" the texts "of a given literary set visible in another", since a significant number of readers were and still are reading in the original language, and there are a lot of visible elements that manage to attract interest without necessarily being translated. Indeed, in this sense, world literature is not regarded merely as the entire mass of translations (Terian 2012, 201). But translations are something that can be quantified at a scale that is large enough to prove something and nonetheless small enough to still show something of use to local literary histories in the age of globalization and transnational academic studies. As Smith claims, "few have managed to forge a research method that negotiates between translation studies and the truly rhizomatic phenomenon of world literature in the modern, transnational world" $(2017,753)$. I am not claiming to have achieved this here, but I believe that we must turn our attention towards empirical grounds when approaching world literature. However, even if we came into possession of the complete archive of world literature (whatever that might entail), reading this archive would still be a local/national/regional matter. Of course, one can claim to read world literature through an abstract and ahistorical mode of reading/interpretative lens. Still, in my understanding, that particular mode of reading simply does not exist outside of the academic consensus that the universal mode of reading is the Western one. This happens, in my view, mainly due to the ideological grounds behind the selection of each translationscape, where many works remain untranslated or are forgotten: the universal mode of reading simple presupposes being unaware of the "obscure satellites". Romanian readerships have a different perception of the French novel than readers in Brazil, for example. And the geographical distance between reading cultures is not the issue here, as readers in Romania also have a different perception of the French or American novel from their neighbors in Bulgaria. Certainly, the recent volumes in Bloomsbury's series of reading national literatures as "world literatures" (Martin, Moraru, and Terian 2018; Coutinho 2019; Harper and Kambourov 2020), are very useful when trying to figure out how the complex matrixes of the transnational can be used in understanding the echoes of national literary production beyond national borders. Yet we also need to consider that every literary work translated into another culture is a small part of a complex translationscape that is ultimately transferred, alongside the abstract image of the entire source culture, into the target one. This image is more or less holistic for readers. Nonetheless, the simple fact that a literature is perceived within a target culture through a local lens, and that translationscapes of different national literatures form various patterns, compels us to consider different experiences of what constitutes world literature. 
The study aims to show how three national literatures functioned within the Romanian subsystem of novelistic translation during communism. An encyclopedic database - the Romanian dictionary of all the novels translated from 1794 to 1989 (Burlacu, Burlacu, Istrate et al. 2005) - will be used to compare the original publication year of every novel with the year of its translation, and in this way three patterns of novelistic translation from 1944 to 1989 will be described. The accuracy of the original publication year for every dictionary entry has been manually verified. The results will be presented in light of relevant contextual information about novels translated within the state-centralized cultural space of communist Romania. First, there was a short period of a certain postwar status quo (from 1944 to 1948) in literary translation, in which French, North American, English, and German novels were still dominating the field. During the second phase (from 1948 to 1964), the Romanian translation program witnessed a radical change. This is also when the first Global South translations emerged in Romania (Baghiu 2019b). In short, prior to 1948, in Romania there were no translations of novels originating in Latin America, Southeast Asia, and Africa. Between 1948 and 1964, a few dozen new cultures were translated. Novels from Ecuador, Mexico, Brazil, Argentina, Bolivia, Uruguay, and other Latin American cultures, novels from China, Korea, Vietnam, and later the Philippines, and novels from Algeria, Egypt, Cameroon, and Senegal were rendered in Romania for the first time in an until then highly Eurocentric translation system (Baghiu 2019b, 500). This can be seen as separated in two distinct periods, one that marks the domination of the Soviet novel in translation (from 1948 to 1955) and a second period of so-called "liberalization" or "thaw", which consisted, in respect to novel translations, of the equal proportion of Eastern (Soviet) novels and Western (Western-European and North-American) novels in translation (from 1955 to 1964; Baghiu 2018). A third phase (from 1964 to 1989) was initiated when socialist realism lost its central position in Romanian culture, and translation programs focused more on translating Western works. This periodization is crucial in relation to what Gisèle Sapiro (2016) defines as the "political (or more broadly ideological)" category of the circulation of world literature in translation, since, as Ioana Popa argues, "far from being limited to a simple operation of translating texts, their transfer from the USSR to its new 'satellites' contributes, under constraint, to modifying writing practices and literary productions there, while supporting the institutional transformations of their cultural worlds" (Popa 2010, 87; see also Popa 2003, 2006).

\section{QUANTITATIVE TRANSLATIONSCAPES: FRENCH, RUSSIAN,} AND AMERICAN

First, let us regard the quantitative translationscape of the French novel. Each dot on the scatter plot is an individual translated novel; however, I chose not to highlight the canonical ones but to observe clusters of time. Of course, the scatter plot does not resemble a constellation, since it is well structured on the horizontal axis (which marks the year of the translation) and the vertical axis (which indicates the year of the original publication of every single novel translated), but it is nonetheless compelling. Placing novels within the translationscape can show both its typical and ab- 
normal presence. For example, a French novel written during 1900 and 1950 and translated between 1948 and 1964 is an exception, so it must be understood as such when referring to particular authors and movements within the target culture. Take, for example, Romain Rolland's L'Âme enchantée, published in 1922 and translated in 1949, only four years after the first translation of Marcel Proust's 1913 Du côté de chez Swann, in 1945. These works are so close and so similar on the translationscape, yet so far apart when considered together. However, my aim here is not necessarily to show how works are placed within the constellation, but rather how we can draw models of different translationscapes in order to understand how translations work within a given literary polysystem (Even-Zohar 1979).

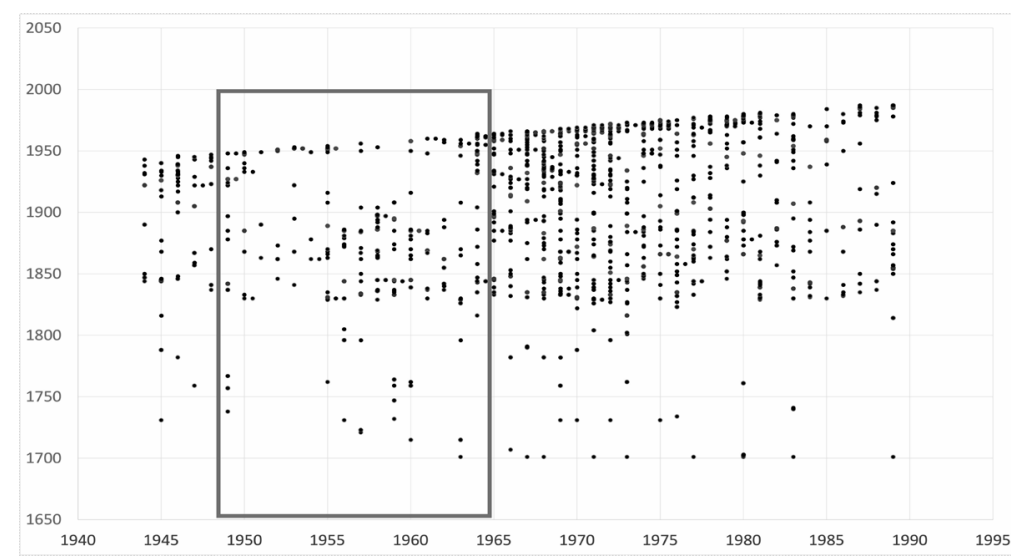

Chart 1: Translationscape 1 - The French novel in Romania with an emphasis on the period of socialist realism (x: 1944-1989; y: 1700-1989)

The French novel has dominated the entire Romanian translation culture since the mid-19th century. From 1800 to 1918 (which can be considered the long 19th century), the French novel covers $70 \%$ of all novelistic translations in Romania (Baghiu 2020a). It maintains its dominance between 1919 and 1944, although I have not yet obtained the necessary data to estimate the proportions of this dominance. However, what is certain is that the only period in Romanian culture from 1800 to 1989 in which the French novel does not hold center stage is the socialist realist period (Baghiu 2018). Still, the chronological translationscape reveals quite exciting things: the French novel persists in translation during socialist realism only through its 19th-century writers. Between 1948 and 1964, the French novels make an appearance in Romania almost exclusively through titles initially published during the 19th century, meaning that the French novel is more out-of-date. But in literature, a greater chronological distance to the year of the publication means, in some cases, what David Damrosch (2006) refers to as hypercanon. Here we have Alexandre Dumas, Eugène Sue, Victor Hugo, Honoré de Balzac, etc., and their presence within the constellation is indisputable. A greater distance within the translationscape gives reassurance during socialist realism that its content is "safe" for readers, while a shorter distance cannot vouch for the ideological purity of the novel. Thus, we can extrapolate that, in turbulent political times, the past is 
a better literary ally. Yet, something had to fill the gap left behind by this boycott of the contemporary and of these recent uncontrollable works of the interwar period. The chronological translationscape of the Russian and Soviet novel can be seen below:

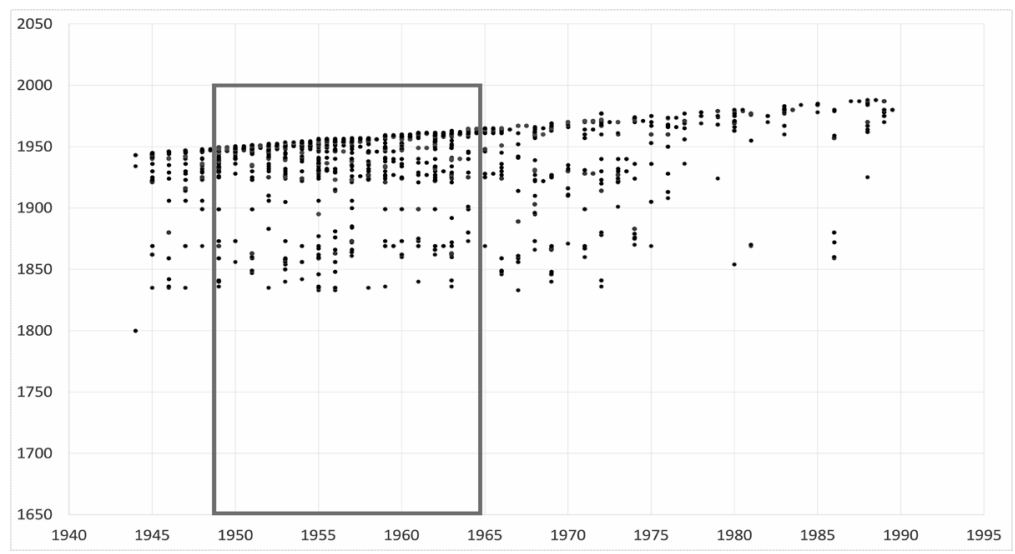

Chart 2: Translationscape 2 - The Russian and Soviet novel in Romania with an emphasis on the socialist realist period (x: 1944-1989; y: 1700-1989)

The Soviet novels translated during the period of socialist realism are authored mainly by contemporary writers, while the French novel only survives through translations of 19th-century authors. While the 19th-century Russian novel goes through a careful selection before appearing in the Romanian translationscape (e.g. authors such as Fyodor Dostoyevsky are not translated or republished during 1944-1955, while Leo Tolstoy is still present), the contemporary Soviet novel fills the gap of contemporaneity itself. Of course, as Katerina Clark shows, there is a visible "Soviet novel" canon within the Russian literary production of the first half of the 20th century, which was exported to the new satellites of the Soviet Union after World War II: "M. Gorky's Mother and Klim Samgin; D. Furmanov's Chapaev; A. Serafimovich's The Iron Flood; F. Gladkov's Cement; M. Sholokhov's Quiet Flows the Don and Virgin Soil Upturned; A. Tolstoy's The Road to Calvary and Peter the First; N. Ostrovsky's How the Steel Was Tempered; and A. Fadeev's The Rout and The Young Guard" $(1981,4)$. This specific canon, alongside other similar authors, rather uniform in their writing and diverse in their socialist realist topics (Baghiu $2020 \mathrm{~b}$ ), provide the sense of the contemporary. It forms a visible cluster within the first decades of Romanian socialist realism (from 1948 to 1964). As has become clear in two quantitative translationscapes, the political program of socialist realism diminished the influence of the Western novel of the first half of the 20th century. Some Soviet novels had already been translated during the interwar period, such writer as Maxim Gorky having ten translated novels between 1905 and 1933 and no translations between 1933 and 1946, due to Romania's interwar farright policies, and Fyodor Gladkov, with two translated novels between 1930 and 1933. Other writers such as Alexander Serafimovich, Alexander Fadeev, or Mikhail Sholokhov became part of the Romanian translationscape only after World War II. 
Yet this is also the situation with some 19th-century authors such as Ivan Goncharov, whose Oblomov (1859) was first translated in Romania after 1949, or Dmitry Mamin-Sibiriak's The Privalov Fortune (1883). ${ }^{3}$ Starting from 1955, the year of Dostoyevsky's reappearance in translation, the Soviet novel translationscape expands to include genre fiction (science fiction, fantasy, adventure novels, through authors such as Vladimir Obruchev), justifying Brian James Baer's assumption that "the fact that translated literature was, as a general rule, less closely monitored than original writing, made it into a vehicle for expressing alternative, if not openly oppositional, views" $(2011,9)$. After 1964 , the Soviet and Russian novel slowly fades away and disappears. The classics had been translated, and contemporary authors had very few things to say after socialist realism. Of course, this was also because Romania tried to distance itself from Moscow and directed its focus to other areas of translation.

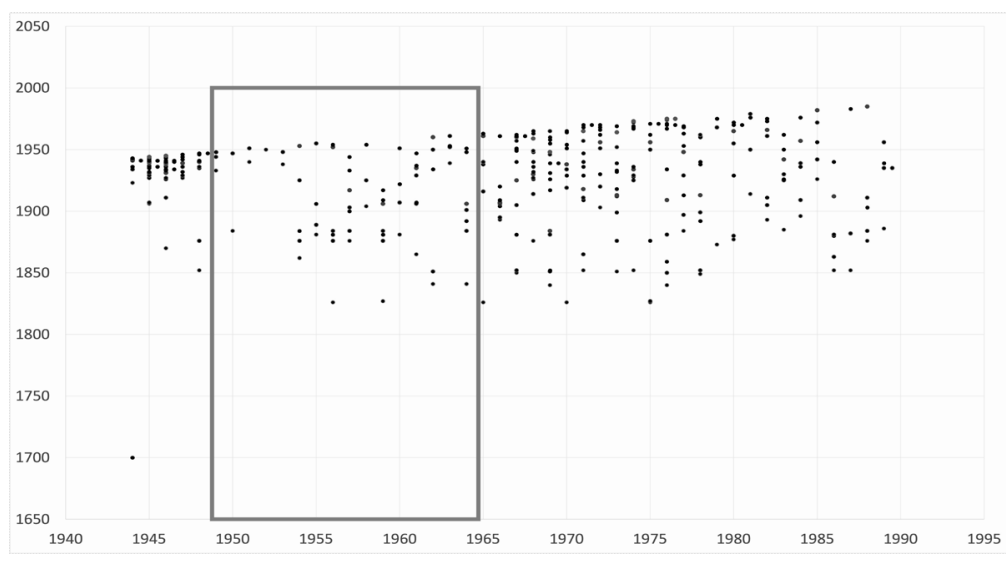

Chart 3: Translationscape 3 - The American novel in Romania (x: 1944-1989; y: 1700-1989)

The relationship between Romanian literature and the North American novel must be understood in political terms as well, even from its very beginnings during the 19th century (Mihăilă 2005; Baghiu 2020a). Although the American novel is more diffuse, it provides us with a translationscape similar to that of the French novel. First, the significant concentration of contemporary novels between 1944 and 1948 points towards the fascination American literature exerted in Europe right after World War II. In the socialist realist period (from 1948 to 1964), the American novel is translated less but appears more chronologically diverse, thus outweighing the French novel of the era between 1919 and 1939. This means that interwar American novels are safer for the regime than the French ones. Novels authored by political writers such as Howard Fast, a very familiar name in socialist realist times, provided a critique of American capitalism as insiders, so they were essential parts of the translation program. After 1964, the American novel becomes a widely acclaimed part of the Romanian translation market, with authors such as William Faulkner or Ernest Hemingway gaining prominence (Schneider 2008). 
To summarize, Soviet literature translated during socialist realism mainly consists of contemporary authors, while the French novel survives in Romanian translation through 19th-century authors only. After 1964, the French novel dominates the field through a compensation process (Terian 2013; Baghiu 2019a), while the Soviet and Russian novels diminish in size within the translationscape. The rise of the American novel is visible during the 1940s but stops during socialist realism and dominates the debates of the last decades of the communist period. This calls for an explanation concerning the circulation of the novel from a big data perspective.

\section{HYPERTRANSLATIONSCAPES, COUNTERTRANSLATIONSCAPES, AND SHADOW TRANSLATIONSCAPES}

As Franco Moretti famously puts it in The Atlas of the European Novel 1800-1900 (1998), drawing on the case of the Dictionary of National Bibliography, "the smaller a collection [of books] is, the more canonical it is" $(1998,146)$. We can imagine that the growth of a literary translationscape is not enacted through canonical works but mainly through shadow canon works. But what does "canon" mean within a translation database, be it only a few thousand novels? Indeed, there are many canonical figures within the shown translationscapes, but the main point of discussion here is quite different: the canonical aspect of each translationscape as a whole, i.e. its amplitude and its persistence. David Damrosch's concepts of hypercanon, countercanon, and shadow canon (2006) can help envision a hypertranslationscape, a countertranslationscape, and a shadow translationscape of novels which can better explain the market and ideological forces shaping the evolution of world literature within a given culture.

These three translationscapes - French, Russian, and American - are illustrated below, with a close-up on the vertical axis for the period between 1800 and 1989 . Of course, emphasizing the canonical novels in relation to the number of articles that were written about them might prove a fruitful method for understanding the brighter stars of the three constellations. However, they are not highlighted here, since clusters can better help us to understand the abstract history of translations.

As David Damrosch implies when he proposes his canonical triad, the canonical status of an author is not necessarily tied to geography or time in a deterministic way. In other words, although there are direct geographical and chronological implications in the formation of the hypercanon ("older 'major' authors who have held their own or even gained ground", 2006, 45), the countercanon ("subaltern and 'contestatory' voices of writers in languages less commonly taught and in minor literatures within great-power languages", 2006, 45), and the shadow canon ("old 'minor' authors who fade increasingly into the background", 2006, 45), this does not mean that French authors are hypercanonical, while Soviet authors constitute the shadow canon. It takes more than their national origin or geographical location, and the discussion must include the dynamics of world literature and translations within the world system, from literary classics like Balzac and Dostoyevsky to new classics, such as Marcel Proust, Virginia Woolf, and William Faulkner, as well as works of authors such as Jorge Amado and Bhabani Bhattacharya. 


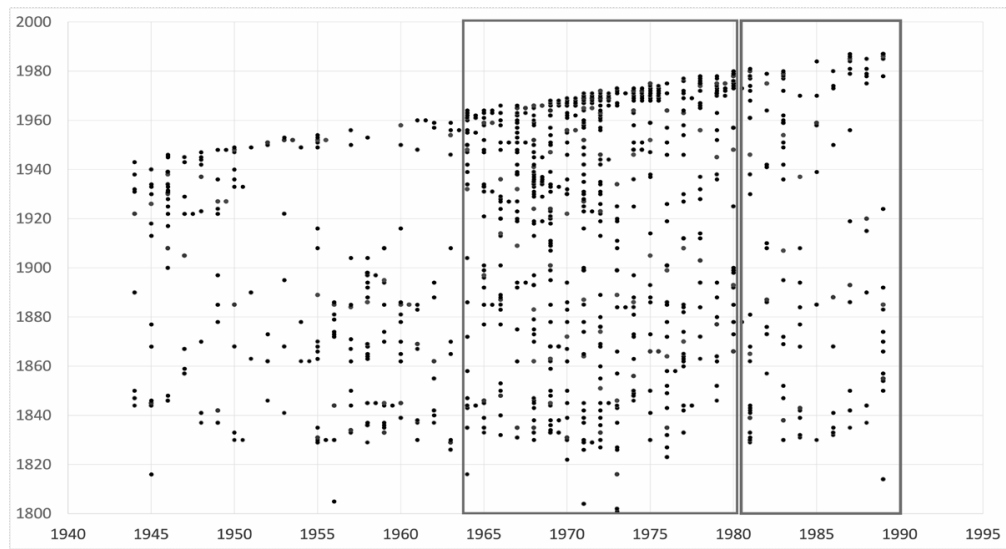

Chart 4: Translationscape 4.a - The French novel in Romania (x: 1944-1989; y: 1800-1989)

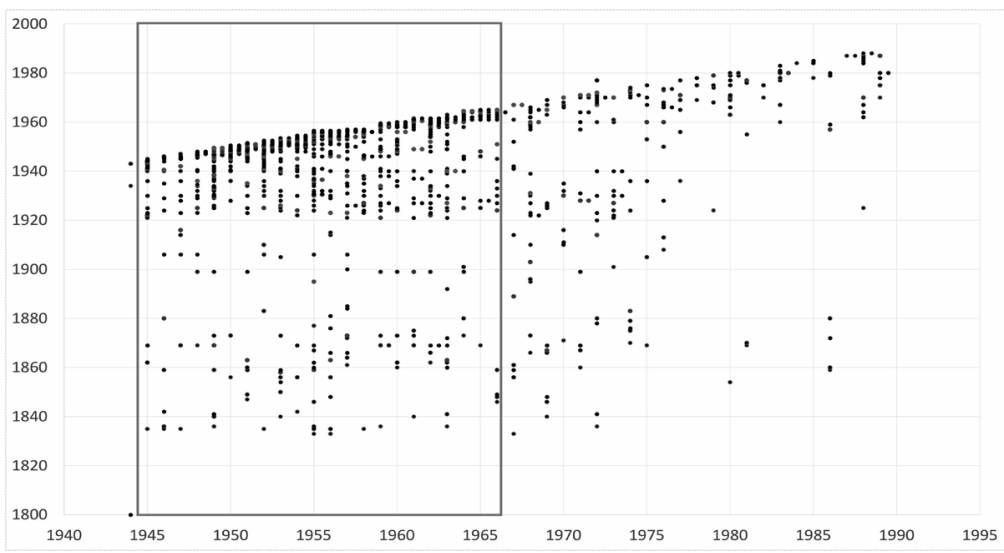

Chart 5: Translationscape 4.b - The Russian novel in Romania (x: 1944-1989; y: 1800-1989)

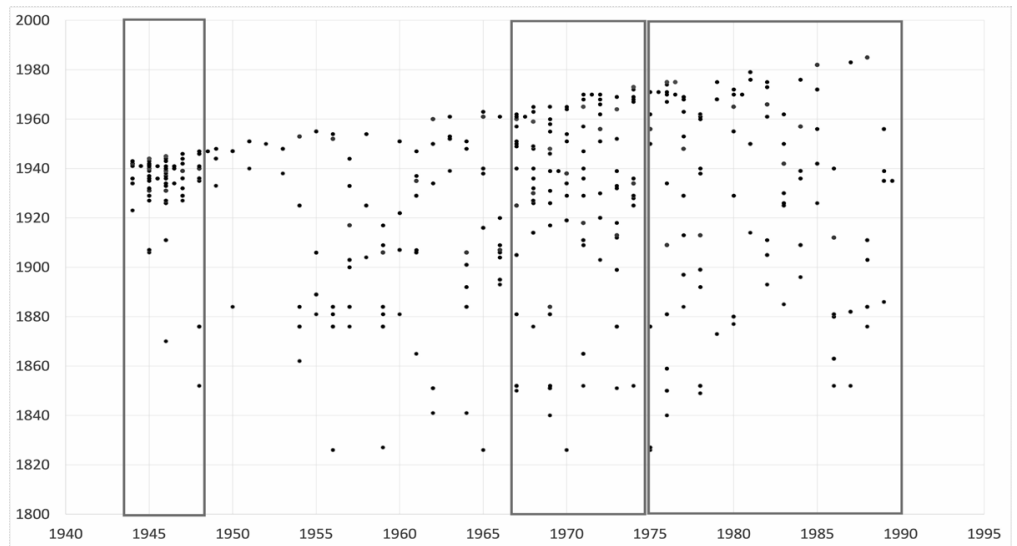

Chart 6: Translationscape 4.c - The American novel in Romania (x: 1944-1989; y: 1800-1989) 
However, I argue that chronological clusters within a translationscape can be decisive for the understanding of the role played by a source literature within a target literature. This perspective on the role of a specific literature is, of course, generated through past and present stereotypes about a particular culture, but is also dependent on the consistency of the clusters within translationscapes.

The Russian and Soviet novel provides the communist period with a shadow translationscape, since it is politically imposed, at least the most consistent cluster (the highlighted square on Chart 5). Its main feature is that it is very present-oriented during socialist realism and it lacks a coherent approach to translations of novels initially published before 1917 . The focus on the contemporary novel in the case of the Soviet novel is driven by the tendency to translate Soviet authors who had achieved a high level of notoriety due to their ties with Moscow's official policy, but most of whom were soon to become part of the shadow canon. In my reading, a shadow translationscape is not a translationscape in which all the translated literature is ephemeral, but in which the central cluster is. A translationscape whose main cluster is doomed to perish entirely within a few decades is one that will, unfortunately, follow the cluster. This does not diminish the target-culture relevance of Dostoyevsky, Tolstoy, Gogol, Gorky and other hypercanonical figures within the shadow translationscape, and not even that of Fadeev and Gladkov, for that matter. But it shows the element that makes it ephemeral: the political obsession with contemporary novels. Although socialist realism was truly the first stage in disseminating African, Southeast Asian, and Latin American literature in Romania, which brought about contestatory voices like Jorge Amado, the shakiness of the core cluster of the Soviet novel is visible and easily understandable. And it generated something strange: Within the shadow translationscape, the hypercanonical 19th-century group of Russian authors loses ground along with the socialist realist cluster, becoming nearly extinct during the 1970s and 1980s, barely surviving through contemporary Soviet authors translated for the sake of bilateral political relations between the empire in ruins (the Soviet Union) and its former satellite (Romania). The presence of the Russian novel is - in this interpretation - shadowed by the dissolution of its main chronological cluster, which had consisted of minor authors with huge political capital within the Soviet Union. In relation to the theory of the great unread, it is overwhelming to think about the massive loss of this cluster: most of the hundreds of novels translated within the cluster have vanished forever and were never coherently integrated within the general Romanian discourse on 20th century Russian literature.

The hypertranslationscape is represented here by the French novel. I have already discussed the cluster of contemporary authors formed between 1944 and 1948 and its shift towards a cluster of 19th-century authors during socialist realism. After 1964, the cluster that stretches towards 1980 is the core of the translationscape, since hundreds of novels from different historical periods were translated at that time. The 19th-century classics with both a hypercanonical and countercanonical status are joined by the early 20th-century modernist authors, who had by then achieved a hypercanonical standing as well, backed up by numerous genre fiction authors that 
have by now been degraded to the status of shadow canon. The hypertranslationscape of the French novel has its core within a much better-disposed cluster of novels, covering chronological distances that had been ignored in the Russian and Soviet translationscape. Above all, the French novel had the capacity to resist the exclusion of the 20th-century novel during socialist realism through its 19th-century works and therefore become the main drive for overcoming the rigid formula of socialist realism. Many modernist or existentialist figures of interwar French literature were redeemed against socialist realism in the sense that they entered Eastern Europe as countercanonical narratives that replaced the Soviet shadow canon.

Last, but not least, is the countertranslationscape: contestatory, hard to assimilate, yet so catchy during the 1960s and throughout the 1980s - the forbidden fruit of the American novel. Although vilified by the main socialist realist critics, since William Faulkner as well as Henry Miller were regarded as depraved writers, it was very inspiring for mainstream Romanian authors such as Marin Preda or D.R. Popescu. The American novel, alongside the Latin American experimental novel, constitutes the contestatory translationscape that follows in the footsteps of the French hypertranslationscape only to contest its dominance, not through quantity, but through its subversive potential.

\section{CONCLUSIONS}

The limitations of this research are quite obvious and derive mainly from the fact that it attempts to analyze the local reception of the novel and limits the novel to three main translationscapes. Also, it avoids the issues of "invisibility" and "untranslability", which are central to translation research and world literature studies alike. Yet time can be a crucial variable in understanding the flows of world literature, especially within its uneven distribution and reception beyond the translation process. Moreover, this is how histories of translations can be conceived with a big data perspective: through quantifiable characteristics that show not only auctorial distribution, but clusters of time within constellations of translations.

\section{NOTES}

1 “Je regardais avec un intérêt mêlé d'une certaine tristesse tant de volumes qui n’ont laissé, pour sauver leur mémoire, qu'un numéro d'ordre et un titre au Journal de la librairie, et je m'arrêtai long-temps devant les poètes, effrayé de leur nombre et tout surpris de trouver à grand'peine dans cette foule quelques noms vaguement connus."

2 “des royautés poétiques, des maîtres qu'on aime et qu'on relit, qui se réimpriment et qui se vendent [...] mais jamais aussi, par compensation, plus de satellites obscurs n’ont gravité autour de la pleïade, et les étoiles nébuleuses forment dans notre ciel une véritable voie lactée."

3 The titles are taken from existing English translations. 


\section{LITERATURE}

Baer, Brian James, ed. 2011. Contexts, Subtexts and Pretexts: Literary Translation in Eastern Europe and Russia. Amsterdam: John Benjamins. DOI: https://doi.org/10.1075/btl.89.

Baghiu, Ștefan. 2018. "Strong Domination and Subtle Dispersion: A Distant Reading of Novel Translation in Communist Romania (1944-1989).” In The Culture of Translation in Romania / Übersetzungskultur und Literaturübersetzen in Rumänien, ed. by Maria Sass, Ștefan Baghiu, and Vlad Pojoga, 63-84. Berlin: Peter Lang. DOI: https://doi.org/10.3726/b15015.

Baghiu, Ștefan. 2019a. "The French Novel in Translation: A Distant Reading for Romania during Communism (1944-1989)." Transylvanian Review 28, Suppl. 1: 83-100.

Baghiu, Ștefan. 2019b. “Translating Hemispheres: Eastern Europe and the Global South Connection through Translationscapes of Poverty." Comparative Literature Studies 56, 3: 487-503. DOI: https:// doi.org/10.5325/complitstudies.56.3.0487.

Baghiu, Ștefan. 2020a. "Translations of Novels in the Romanian Culture during the Long Nineteenth Century (1794-1914): A Quantitative Perspective." Metacritic Journal for Comparative Studies and Theory 6, 2: 87-106. DOI: https://doi.org/10.24193/mjcst.2020.10.05.

Baghiu, Ștefan. 2020b. “The Socialist Realist Novel in Romania between 1948 and 1955. Novelistic Genres and Subgenres." Dacoromania Litteraria VII: 56-71. DOI: https://doi.org/10.33993/drl.2020.7.56.71.

Burlacu, Doru, Liliana Burlacu, Ion Istrate et al. 2005. Dicţionarul cronologic al romanului tradus în România de la origini până în 1989 [Chronological dictionary of novels translated in Romania from its origins to 1989]. Bucureşti: Editura Academiei Române.

Clark, Katerina. 1981. The Soviet Novel: History as Ritual. Chicago, IL: University of Chicago Press.

Cohen, Margaret. 1999. The Sentimental Education of the Novel. Princeton, NJ: Princeton University Press.

Coutinho, Eduardo F., ed. 2018. Brazilian Literature as World Literature. New York, NY: Bloomsbury.

Damrosch, David. 2006. "World Literature in a Postcanonical, Hypercanonical Age." In Comparative Literature in an Age of Globalization, ed. by Haun Saussy, 43-53. Baltimore, MD: Johns Hopkins University Press.

Damrosch, David. 2009. "Frames for World Literature." In Grenzen der Literatur: Zu Begriff und Phänomen des Literarischen, ed. by Simone Winko, Fotis Jannidis, and Gerhard Lauer, 496-515. Berlin and NewYork, NY: De Gruyter. DOI: https://doi.org/10.1515/9783110210835.6.496.

Escarpit, Robert. 1966. The Book Revolution. London: George G. Harrap \& Co. LTD.

Even-Zohar, Itamar. 1979. "Polysystem Theory." Poetics Today 1, 1-2: 287-310.

Harper, Mihaela P., and Dimitar Kambourov, eds. 2020. Bulgarian Literature as World Literature. New York, NY: Bloomsbury.

Harrison, Nicholas. 2014. "World Literature: What Gets Lost in Translation?" The Journal of Commonwealth Literature 49, 3: 411-426. DOI: https://doi.org/10.1177/0021989414535420.

Jockers, Matthew L. 2013. Macroanalysis: Digital Methods and Literary History. Chicago, IL: University of Illinois Press.

Louandre, Charles. 1842. “Statistique littéraire: La Poésie depuis 1830.” Revue des Deux Mondes, période initiale 30: 971-1002.

Martin, Mircea, Christian Moraru, and Andrei Terian, eds. 2018. Romanian Literature as World Literature. New York, NY : Bloomsbury.

Mihăilă, Rodica. 2005. "The Politics of Translation: The American Novel in the 19th Century Romanian Territories." B.A.S. - British and American Studies XI: 285-291.

Moretti, Franco. 1998. Atlas of the European Novel 1800-1900. London: Verso.

Moretti, Franco. 2000a. "Conjectures on World Literature." New Left Review 1: 54-68.

Moretti, Franco. 2000b. “The Slaughterhouse of Literature." Modern Language Quarterly 61, 1: 207-227.

Moretti, Franco. 2013. Distant Reading. London: Verso.

Popa, Ioana. 2003. "Le réalisme socialiste, un produit d'exportation politico-littéraire." Sociétés et représentations 15, 1: 261-292. DOI: https://doi.org/10.3917/sr.015.0261.

Popa, Ioana. 2006. "Translation Channels: A Primer on Politicized Literary Transfer." Target 18, 2: 205-228. DOI: https://doi.org/10.1075/target.18.2.02pop.

Popa, Ioana. 2010. Traduire sous contraintes: Littérature et communisme (1947-1989). Paris: CNRS Éditions. 
Sapiro, Gisèle. 2016. "How Do Literary Works Cross Borders (or Not)? A Sociological Approach to World Literature." Journal of World Literature 1, 1: 81-96. DOI: https://doi.org/10.1163/2405648000101009 .

Schneider, Ana-Karina. 2008. "William Faulkner and the Romanian 'Criticism of Survival"' Faulkner Journal 24, 1: 99-117.

Smith, Jordan A.Y. 2017. "Translationscapes: On the Legibility of Transnational Ideologies in World Literarary Systems." Comparative Literature Studies 54, 4: 749-770. DOI: https://doi.org/10.5325/ complitstudies.54.4.0749.

Terian, Andrei. 2012. "Reading World Literature: Elliptical or Hyperbolic? The Case of Second-World National Literatures." Interlitteraria 17, 1-2: 17-26. DOI: https://doi.org/10.12697/IL.2012.17.03.

Terian, Andrei. 2013. "National Literature, World Literatures, and Universality in Romanian Cultural Criticism 1867-1947." CLC Web: Comparative Literature and Culture 15, 5. DOI: https://doi. org/10.7771/1481-4374.2344.

Terian, Andrei. 2019. "Big Numbers: A Quantitative Analysis of the Development of the Novel in Romania.” Transylvanian Review 28, Suppl. 1: 55-74.

Venuti, Lawrence. 2017. The Translator's Invisibility: A History of Translation. London: Routledge.

\section{Quantitative translationscapes and chronological constellations: French, Soviet, and American novels in communist Romania}

Translationscape. Translation history. World literature. Romanian communism. Canon formation.

This article makes use of quantitative methods to chart the particular morphologies of translated novels in Romania after World War II. The three charts presented show the chronological shift in the preferences for translating novels in a comprehensive account of all the Russian (and Soviet), French, and American novels translated in Romania, demonstrating that the translations can be analyzed through what Jordan A.Y. Smith convincingly argues to be a useful model in translation studies and world literature, namely translationscapes. Through use of an extensive database, the article illustrates which periods the novels translated in communist Romania originate from and describes three patterns of translation during communism according to David Damrosch's approach to canon. This points towards a certain need for clarifying the circulation of the novel from a big data perspective, through what this study refers to as quantitative translationscapes.

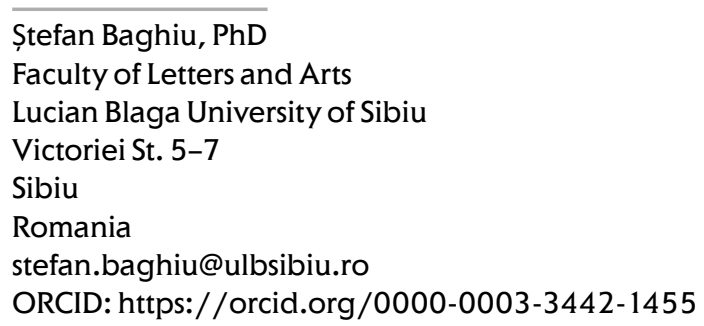

